\title{
GENETIC DETECTION AND PATHOLOGICAL FINDING OF BVDV AND BHV-1 IN CAMEL CALVES
}

\author{
JEHAN A. GAFER ; THANAA K. HASSANEEN ${ }^{* *} ;$ HALA A. SALEM $^{* * * *}$ and MADBOLY. $\mathbf{M}^{* * * *}$ \\ *Biotechnology Unit, Animal Reproduction Research Institute \\ *** Pathology Department, Animal Reproduction Research Institute \\ ${ }^{* * *}$ Reproduction Disease Department, Animal Reproduction Research Institute \\ ***** Camel Research Department, Animal Production Research Institute.
}

Email: jehan.gafer@gmail.com

Assiut University web-site: www.aun.edu.eg

Received at: 18/6/2015

Accepted: 30/6/2015

\section{ABSTRACT}

The objectives of this study are directed to employ multiplex PCR assay and some virological techniques for detection of bovine viral diarrhea virus (BVDV) and bovine herps virus-1 (BHV-1) in clinical samples with clarification of their pathological effects on camel calves. A total of 124 different types of samples were collected from 43 camel calves (clinically ill $n=28$, apparently healthy $n=10$ and recently dead camel calves $n=5$ ), from two different localities in Egypt. All samples were subjected to virological (immunoflurece and immunoperoxidase) and molecular investigation. Tissue samples from recently dead animals were subjected to histopathological studies. BHV-1 was detected in $6(13.95 \%)$ using immunoflurece versus to $7(16.27 \%)$ by immunoperoxidase while BVDV was detected with same percentage (11.62\%) in both techniques. Results of PCR demonstrated a specific amplicon of $389 \mathrm{bp}$ indicating the presence of BHV-1 in $8(21.21 \%)$ out of examined 33 clinically ill animals. While successful amplification of $288 \mathrm{bp}$ indicating the presence of BVDV in $6(13.95 \%)$ out of total 43 animals under investigation. Histopathological examinations revealed encephalitis and necrosis in the brain with interstitial lymphocytic pneumonia. Lymphocytic portal hepatitis, hyperplasia of spleen follicles, ulcerative enteritis and hemorrhagic lymphadenitis were observed. Results concluded that the use of multiplex PCR can be a rapid cost-effective way for simultaneous detection so that consider a valuable practical diagnostic tool for BVDV and BHV-1 in clinical samples. Immunoflurecent and immunoperoxidase regard as simple confirmative tools for identification of both viruses. This study confirmed the lesions in several organs of camel calves infected with BVD and BHV-1.

Key words: Camel calves - BVDV - BHV-1 - multiplex PCR assay - Immunofluorescence - Histopathology.

\section{INTRODUCTION}

Camels are considered an important source for human food, transportation and entertainment especially in the Arab countries (Mohamed et al., 2013).

Contrary to the OIE rules, camels enter Egypt officially without any virological investigation, or sufficient period for quarantine. Therefore, the continuous importation of viraemic camels, from Sudan was the main source of many critical viral outbreaks in Egypt (Abd-Elrahim et al., 1999; Mohamed et al., 2013).
BVDV and BHV-1 are important worldwide pathogens that primarily infect cattle and other ruminants and are associated with serious economic impact to the animal production sector as causing losses from reproductive failures and increase the severity of secondary infections by other pathogens (Ackermann and Engels, 2006).

Bovine Virus Diarrhea (BVD) causes substantial damage in infected herds (Moennig et al., 2005; Ahmed and Kawther 2008). In camel, BVDV is considered as the cause of death in both New World Camelids (NWC) and Old World Camelids (OWC) and has been associated with cases of diarrhea, 
stillbirth, intrauterine death and neonatal mortalities (Wentz et al., 2003). Abd-El Wahab et al. (2005) confirmed the existence of BVDV among camel population and raise the possibility of the presence of persisting infected camels by BVDV which may cause extensive shedding of the virus among camel population. Such fact results in severe outbreaks. Bovine viral diarrea in newly born camel calf developed severe diarrhea. Histopathologic lesions consist of atrophy and fusion of small intestine villi, lymphocyte depletion of primary and secondary lymphoid organs (Kapil et al., 2009; Amstel and Kennedy, 2010; John 2014; Oguzhan et al., 2014).

Bovine viral diarrhea virus is a member of the pestivirus genus family Flaviviridae. The genome of pestivirus consists of a single stranded linear RNA about $12.5 \mathrm{~kb}$ in size (Byers et al., 2011). The Virus associated with pathology in several physiologic systems including reproductive, respiratory, gastrointestinal, circulatory, immunologic lymphatic, musculo skeletal and central nervous (Brock 2004).

Bovine Herpes Virus type 1 (BHV-1) belongs to the Herpesviridae family, genus varicella virus (OIE, 2010). The genome consists of double-stranded DNA (Deregt, 1998).

Many of previous studies recorded IBR in newborn calves as a fatal generalized systemic disease, characterized by profuse nasal discharge, lesions of the alimentary tract with diarrhea (Curtis 2001; Meyer et al., 2001; Tariq 2007; Dragoş et al., 2010). Lesions are usually related to the upper respiratory tract and include: swelling and congestion of mucosa, sometimes with necrotic foci, petechiae, profuse and fibrinopurulent exudate in severe cases. It can be detected in nasal swaps by immunofluorescence technique, ELISA, immunoperoxidase and PCR (ElSabbagh et al., 2000; Mohamed et al., 2013). Evidence of BHV-1 infection in OWC is limited but a higher prevalence has been reported in NWC and OWC when grazing pastures are shared with other ruminants (Wernery and Kaaden 1995).

As these viral pathogens cause very similar clinical signs, differential diagnosis of the pathogens is an important step in the proper treatment of the infected animals. Therefore, the objectives of this work directed to employ a multiplex PCR assay for simultaneous detection of BVDV and BHV-1 and simple virological in clinical samples, and clarify their pathological effects on camel calves.

\section{MATERIALS and METHODS}

Animals: Forty three dromedary camel calves were used for this work (10 normal, 28 suspected clinically ill and 5 recently dead). The animals were housed in two areas. These areas are: Camel studies and production Development Center in Matrouh Governorate belonging to Animal Production Research Institute (APRI), ARC: other site was Private Camel Farms in Al-Sharkiya Governorate.

Samples: A total number of 124 different samples (38 blood serum, 28 nasal swabs and 28 fecal swabs) were collected for virological and molecular studies, while 30 tissue samples were taken from the internal organs of recently dead camel calves for histopathological studies. The localities, number and types of samples are recorded in Table (1).

Viral strains: BVDV-NADL a reference strain with a titer $10^{7} \mathrm{TCID}_{50}$ and BHV-1 Clorado strain with a titer $10^{6} \mathrm{TCID}_{50}$ kindly supplied from Virology Department, A.H.R.I.

Antibodies: Antibovine herps virus -1 serumantibovine virus diarrhea serum

Cells: Madin-Darby bovine kidney (MDBK) cells were grown in Earle's medium (DMEM) supplemented with 10\% BVDV-free fetal bovine serum (FBS) and antibiotics.

Conjugates: Staphylococcal protein $-\mathrm{A}$ conjugated with flourescein isothionate for IF assay Staphylococcal protein -A conjugated with horse raddish peroxidase for IMP assay kindly provided from Dr. Mohammed Saad prof. of microbiology A.R.R.I.

\subsection{Virological Studies:}

2.1.1. Indirect immunofluorescent (IF) technique: The IF technique was carried out as the method described by OIE (2008) to identify both viruses. Three blind passages of the tested samples were done on cell cultures and the third passage was conducted to indirect IF technique. Both positive and negative control samples were also included. The tested samples were considered positive when there was a clear apple green fluorescence in the infected cell culture, while the negative control and non-infected cells, showed no fluorescence.

2.1.2. Immunoperoxidase (IMP) for viral detection: Detection of BVDV and BHV-1 virus by immunoperoxidase was performed according to OIE (2008). Briefly, the inoculated plates were incubated at $37^{\circ} \mathrm{C}$ for $\mathrm{CPE}$, then cell fixed with cold acetone (20\%) and dried at room temperature for $3 \mathrm{~h}$. Antibodies $(50 \mu \mathrm{l})$ were added to all wells and incubated at $37^{\circ} \mathrm{C}$ for $1 \mathrm{hs}$. Thereafter, 50ul conjugate was added and incubated for $1 \mathrm{hs}$ at $37^{\circ} \mathrm{C}$. Finally, freshly prepared hydrogen peroxide substrate was added and the plate is examined microscopically. Virus-positive cells show brown cytoplasmic staining. 
2.1.3. Immunoperoxidase (IMP) for antibody detection: The test was performed according to (Saliki et al., 1997) with some modification to adapt antibodies detection instead of viral detection for detection of both viruses antibodies.

\subsection{Molecular assay:}

\subsubsection{Nucleic acid Extraction:}

2.2.1.1. RNA Extraction: RNA was extracted from nasal, fecal swabs, serum and tissue samples as well as reference strain (BVDV-NADL strain) using Biozol (Total RNA Extraction Reagent) Bioflux Cat\# BSC51M1 according to manufacture instructions using 200mg of sample and $1 \mathrm{ml}$ of Biozol.

\subsubsection{DNA extraction: DNA was extracted from} nasal swabs or homogenized tissue as well as reference strain (BHV-1 Colorado strain) according to Jerzy et al. (2005). Briefly, 300ul of samples was added to proteinase $\mathrm{K}(25 \mathrm{mg} / \mathrm{ml})$ and $25 \mu \mathrm{l}$ of $10 \%$ SDS. DNA was purified using phenol: chloroform method precipitated with $3 \mathrm{M}$ sodium acetate and 96\% ethanol. Precipitated DNA pellet was then resuspended in $30 \mu \mathrm{l}$ of distilled water and $4 \mathrm{ul}$ used as a template in PCR amplification.

2.2.3. cDNA synthesis: 5ul of RNA template was reverse transcribed to cDNA at $25^{\circ} \mathrm{C}$ for $5 \mathrm{~min}$ followed by incubation at $42^{\circ} \mathrm{C}$ for $60 \mathrm{~min}$. Finally the reverse transcription reaction was stopped by heating the samples to $70^{\circ} \mathrm{C}$ for $5 \mathrm{~min}$. using Revert $\mathrm{Aid}^{\mathrm{TM}} \mathrm{H}$ Minus First strand cDNA synthesis Kit (Fermentas Life sciences Lot: 00059751) according to manufacture instructions.

2.2.4. PCR amplification: Amplifications were performed in $25 \mu \mathrm{l}$ reactions containing $5 \mathrm{ul}$ of genomic DNA, 1X of master mix (Dream Taq Green PCR master Mix, Fermentas Life Science) and 25 pmol of each primer were used the detailed sequence presented in Table (2). The PCR amplification cycling protocol were presented in Table (3).

2.2.5. Analysis of PCR products: The analysis was carried out according to Sambrook et al. (1989) using $1.5 \%$ ethidium bromide stained agarose gel and visualized under ultraviolet transilluminator.

2.3. Histopathological Study: All tissue samples (Brain-lung- liver- spleen- part of small intestine (ileum) and mesenteric lymph node) were fixed in natural buffer formalin washed, dehydrated by alcohol, cleared in Xylen and embed in paraffin. Tissues were sectioned at $3 \mathrm{u}$ thickness and stained with H\&E for microscopical examination according to Bancroft and Stevens (1990).

\section{RESULTS}

\section{1. Clinical signs:}

Clinical manifestations appeared on the camel calves in Mattroh and El-sharkia farms were fever $\left(41.5^{\circ} \mathrm{C}\right)$, anorexia, listlessness, respiratory signs, dyspnoea, hyperaemia of the nasal mucosa, and serous discharge from eyes and nose, diarrhoea then occasional death of 2 calves in Mattroh farm and 3 calves in El-sharkia farms were observed. All dead calves were nearly 2 months of age.

3. 2. Virological results: Positive samples for BVD and $\mathrm{BHV}-1$ were characterized using IF by specific intranuclear and intracytoplasmic apple green fluorescence respectively Fig. (1) While IMP-stained infected cell monolayers produced intense brown intranuclear and intracytoplasmic staining for BHV-1 and BVD respectively Fig. (2). The results of immunofluorescent technique and IMP are represented in Table (4) where BHV-1 was detected in $6(13.95 \%)$ out of 43 camel calves under investigation using IF teqnique versus to $7(16.27 \%)$ detected by IMP assay. On the other hand, BVDV and infection with both viruses were detected with same percentages (11.62\%) using both techniques. Concerning to antibodies detection for $\mathrm{BHV}-1$ in serum of the apparently health camel calves there were no antibodies detected (data not shown).

\section{3. Molecular Results:}

Regarding the results of multiplex PCR the amplicons of the expected size were obtained with the two primer pairs 288bp and 389bp for BVDV and BHV-1 respectively Fig (3). With reference to the data presented in Table (5) BHV-1 was detected in 8 $(21.21 \%)$ out of 33 clinically ill camel calves investigated while BVDV and infection with both viruses were detected in $6 / 43(13.95 \%)$ and $3 / 43$ $(6.97 \%)$ respectively.

\section{4. Histopathological results:}

Brain: 1. Macroscopical examination of dead camel calves revealed edema and congestion of the meanings (fig.4-picture-A).

2. Microscopic examination: The most pronounced histopathological changes in the brain of the camel calves were edema associated with necrobiotic changes of neuroglia cells which showed chromatolysis (fig.4 slide B). The cerebral blood vessels showed edema, congestion and lymphocytic perivascular cuffing associated with mononuclear cells infiltration and gliosis (Fig.4 slide C).

Lung: 1. Macroscopical examination of dead animals revealed inflammation and consolidation of the diaphragmatic and apical lobes in the right and left lungs. There were some adhesions between lungs and the pleura. The cut surface of the lung was 
frothy. Congestion, emphysema and atelectasis were also observed (fig.5-picture- A).

2. Microscopic examination revealed desquamation of the lining epithelium of the bronchi with focal accumulation of the inflammatory cells mostly lymphocytes and increased the interalveolar septa (Fig.5 slide B) and desquamation of cellular exudates admixed with exfoliated necrotic epithelial cells in the bronchial lumina with fibroblastic proliferation (Fig. 5 slide C).

Spleen: 1. Macroscopical examination revealed morbid edematous and congested organ (fig.6picture-A).

2. Microscopic examination revealed hyperplasia of splenic follicle (fig.6 slide B) with edema (fig.6 slide C) and focal suppuration (live \&dead neutrophiles) (fig.6 slide D).

Liver: 1. Macroscopical examination revealed edematous, congested and hyperemic organ (fig.7picture-A).

2. Microscopic examination revealed edema with vacuolar degeneration of hepatocytes and inflammatory cells aggregation in the portal area (fig.7 slide B). Degenerated and necrosed hepatocytes with focal heamorrhges and congestion of blood vessels (fig.7 slide C).

Small intestine: 1. Macroscopical examination of the ileum revealed edema, congestion with ulcers on the peyer's patches (fig. 8 picture-A).

2. Microscopic examination revealed degeneration of the intestinal villi with desquamation of its lining epithelium and diffuse inflammatory cells infiltration mainly lymphocytes and neutrophiles (fig. 8 slide B). Degeneration of the intestinal glands and necrosis of others together with edema and inflammatory cells aggregation in the lamina propria were observed (fig.8 slide $\mathrm{C}$ ).

Mesenteric Lymph Node: 1. Macroscopical examination revealed congestion and heamorrhge (fig.9 picture-A)

2. Microscopic examination revealed follicular hyperplasia with dense infiltration of inflammatory cells mainly lymphocytes and plasma cells (fig.9 slide B). Edema with subcapsular heamorrhges (fig.9 slide $\mathrm{C}$ ).

Table 1: Number and types of samples of camels collected from the target areas for detection of BVD and BHV-1

\begin{tabular}{|c|c|c|c|c|c|c|c|c|}
\hline \multirow{3}{*}{ Target area } & \multirow{3}{*}{\multicolumn{2}{|c|}{ Animal status }} & \multirow{3}{*}{$\begin{array}{c}\text { No. of } \\
\text { animals }\end{array}$} & \multicolumn{4}{|c|}{ Type \& No. of Samples } & \multirow{3}{*}{$\begin{array}{l}\text { Total of } \\
\text { samples }\end{array}$} \\
\hline & & & & \multirow{2}{*}{ Serum } & \multicolumn{2}{|c|}{$\begin{array}{c}\text { Nasal and } \\
\text { Fecal swab }\end{array}$} & \multirow{2}{*}{$\begin{array}{c}\text { Tissue } \\
\text { samples }\end{array}$} & \\
\hline & & & & & N.S. & F.S. & & \\
\hline \multirow{3}{*}{$\begin{array}{c}\text { Matrouh } \\
\text { Camel Center } \\
\text { (APRI) }\end{array}$} & \multirow{2}{*}{$\begin{array}{l}\text { Suspected } \\
\text { cases }\end{array}$} & Clinically sick & 21 & 21 & 21 & 21 & - & 63 \\
\hline & & $\begin{array}{l}\text { recently dead } \\
\text { camel calf }\end{array}$ & 3 & - & - & - & 18 & 18 \\
\hline & \multicolumn{2}{|c|}{ Clinically normal } & 6 & 6 & - & - & - & 6 \\
\hline \multirow{4}{*}{$\begin{array}{c}\text { Sharkiya } \\
\text { private camel } \\
\text { farms }\end{array}$} & & Clinically sick & 7 & 7 & 7 & 7 & - & 21 \\
\hline & $\begin{array}{c}\text { Suspected } \\
\text { cases }\end{array}$ & $\begin{array}{l}\text { recently dead } \\
\text { camel calf }\end{array}$ & 2 & - & - & - & 12 & 12 \\
\hline & \multicolumn{2}{|c|}{ Clinically normal } & 4 & 4 & - & - & - & 4 \\
\hline & \multicolumn{2}{|c|}{ Total numbers } & 43 & 38 & 28 & 28 & 30 & 124 \\
\hline
\end{tabular}

Table 2: Primers used in PCR amplification

\begin{tabular}{cccc}
\hline Target & Sequnce5'-3' & Amplicon size & Reference \\
\hline & (5'- ATGCCCWTAGTAGGACTAGCA -3') & 288bp & Tramuta et al. \\
BVDV 5'UTR & (5'- TCAACTCCATGTGCCATGTAC -3') & & (2011) \\
\hline BHV-1 glycoprotein C & (5'- TGTGACTTGGTGCCCATGTCGC -3') & 389bp & \\
& (5'- GAGCAAAGCCCCGCCAAGGAG -3') & & \\
\hline
\end{tabular}


Assiut Vet. Med. J. Vol. 61 No. 146 July 2015

Table 3: Cycling protocol of multiplex PCR for amplification of BVDV and BHV-1

\begin{tabular}{|c|c|c|c|c|c|}
\hline \multirow[t]{2}{*}{ Target } & \multirow{2}{*}{$\begin{array}{l}\text { Amplicon } \\
\text { size }\end{array}$} & \multicolumn{3}{|c|}{ Cycling condition } & \multirow[t]{2}{*}{ No. of cycle } \\
\hline & & Step & Temp. & Time & \\
\hline BVDV 5'UTR & $288 b p$ & $\begin{array}{c}\text { Initial } \\
\text { denaturation }\end{array}$ & $9^{\circ} \mathrm{C}$ & $15 \mathrm{~min}$. & One cycle \\
\hline \multirow{4}{*}{$\begin{array}{c}\text { BHV-1 glycoprotein } \\
\text { C }\end{array}$} & \multirow{4}{*}{ 389bp } & Denaturation & $94^{\circ} \mathrm{C}$ & I min. & \multirow{3}{*}{35 cycles } \\
\hline & & Anealing & $55^{\circ} \mathrm{C}$ & $1 \mathrm{~min}$. & \\
\hline & & Extension & $7^{\circ} \mathrm{C}$ & $1 \mathrm{~min}$. & \\
\hline & & Final extension & $7^{\circ} \mathrm{C}$ & $10 \mathrm{~min}$. & One cycle \\
\hline
\end{tabular}

Table 4: Results of immunoflurescence and immunoperoxidase assays for detection of BVD and BHV-1 antigens

\begin{tabular}{|c|c|c|c|c|c|c|c|}
\hline \multirow[t]{3}{*}{ Status of animal } & \multirow{3}{*}{$\begin{array}{l}\text { No. of } \\
\text { animal }\end{array}$} & \multicolumn{6}{|c|}{ Results of IF and IMP assays } \\
\hline & & \multicolumn{3}{|c|}{ No. of +ve IF } & \multicolumn{3}{|c|}{ No. of +ve IMP } \\
\hline & & BHV-1 & BVD & Both & BHV-1 & BVD & Both \\
\hline Clinically ill & 28 & 5 & 3 & 1 & 6 & 3 & 1 \\
\hline $\begin{array}{l}\text { Apparently } \\
\text { healthy }\end{array}$ & 10 & - & - & - & - & - & - \\
\hline $\begin{array}{l}\text { Recently dead } \\
\text { camel calves }\end{array}$ & 5 & 1 & 2 & 1 & 1 & 2 & 1 \\
\hline Total & 43 & $\begin{array}{c}6 / 43 \\
(13.95 \%)\end{array}$ & $\begin{array}{c}5 / 43 \\
(11.62 \%)\end{array}$ & $\begin{array}{c}2 / 43 \\
(4.65 \%)\end{array}$ & $\begin{array}{c}7 / 43 \\
(16.27 \%)\end{array}$ & $\begin{array}{c}5 / 43 \\
(11.62 \%)\end{array}$ & $\begin{array}{c}2 / 43 \\
(4.65 \%)\end{array}$ \\
\hline
\end{tabular}

BHV-1= Bovine herps virus $-1, \mathrm{BVD}=$ Bovine viral diarrhea

Table 5: Results of multiplex PCR for detection of BVD and BHV-1 nucleic acids

\begin{tabular}{ccccc}
\hline & \multirow{2}{*}{$\begin{array}{c}\text { No. of } \\
\text { Animal status }\end{array}$} & animals & & \multicolumn{2}{c}{ Result of multiplex-PCR } \\
\cline { 3 - 5 } & & No. of +Ve for BHV-1 & No. of+Ve for BVD & $\begin{array}{c}\text { No. of +ve Both } \\
\text { viruses }\end{array}$ \\
\hline Clinically normal & 10 & ND & 1 & - \\
\hline Clinically ill & 28 & - & 4 & 1 \\
\hline Recently dead camel calves & 5 & $83 / 33(21.21 \%)$ & $6 / 43(13.95 \%)$ & $3 / 43(6.97 \%)$ \\
\hline Total & 43 & & & 2
\end{tabular}

$\mathrm{ND}=$ not done, $\mathrm{BHV}-1=$ Bovine herps virus $-1, \mathrm{BVD}=$ Bovine viral diarrhea 

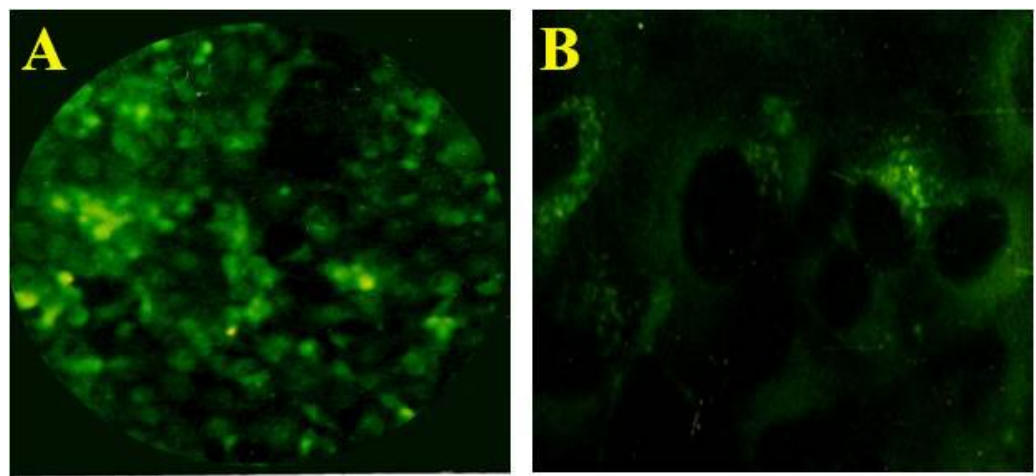

Fig. (1): Positive intranuclear apple green fluorescence of BHV-1(A), intracytoplasmic fluorescence of BVD virus (B)
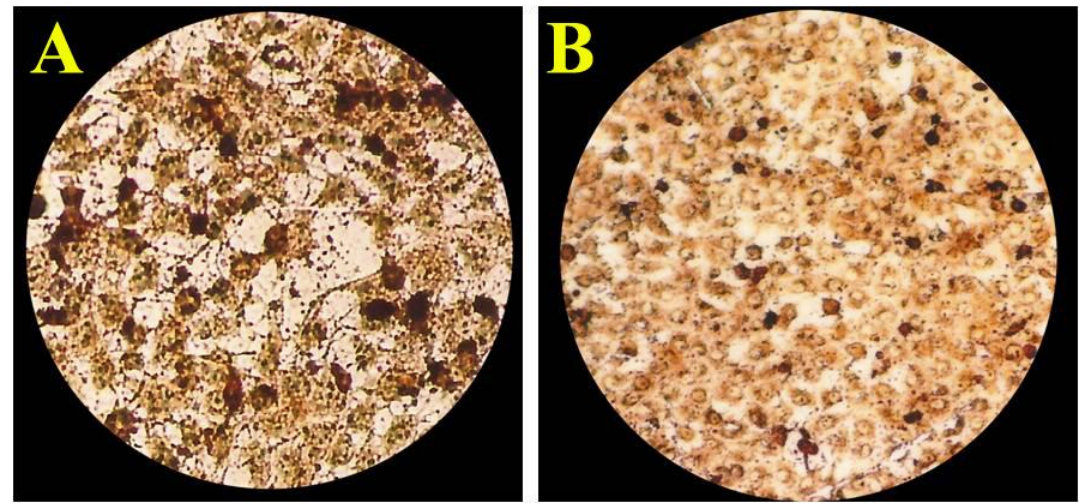

Fig. (2): Positive immunoperoxidase of intranuclear (A) and intracytoplasmic (B)brown stain of BHV-1 and BVDV viruses

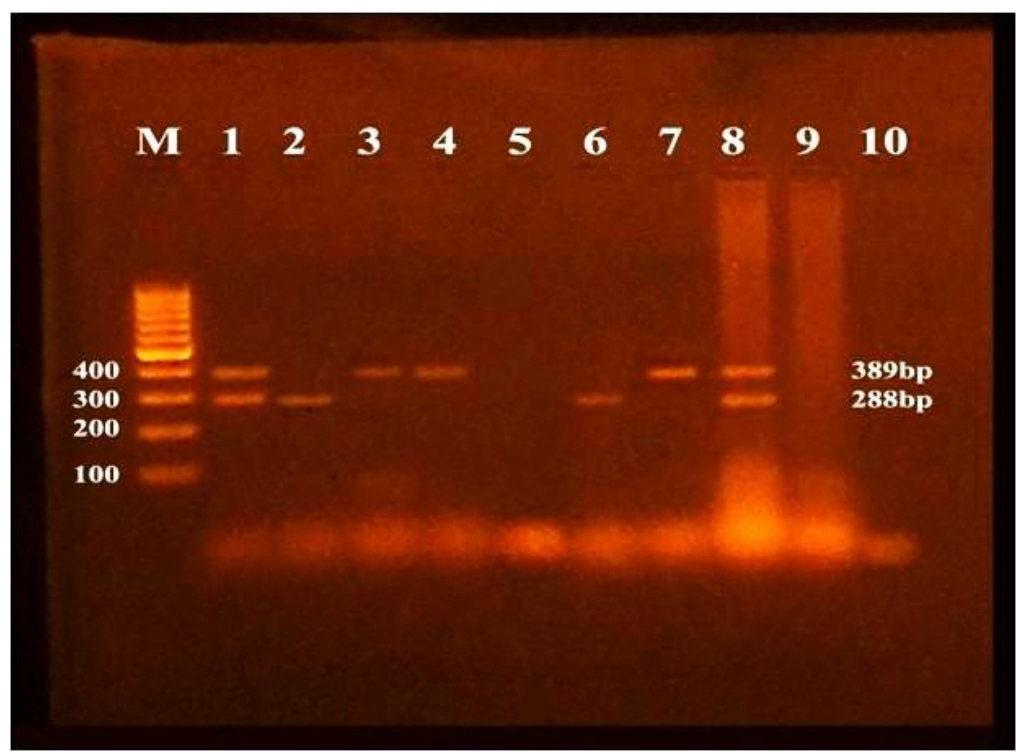

Fig. (3): Shows ethidium bromide stained 1.5\% agarose gel electrophoresis of Multiplex PCR products. Lane M: 100bp DNA ladder, Lane 1: positive controls of both viruses (BHV-1 389bp and BVD 288bp), Lanes (2 ,6): Positive samples for BVDV 288bp, Lanes (3,4,7): Positive samples for BHV-1 389bp, Lane 8: Positive sample for BHV-1 and BVDV, Lanes (5,9): Negative samples, Lane 10: Negative control 

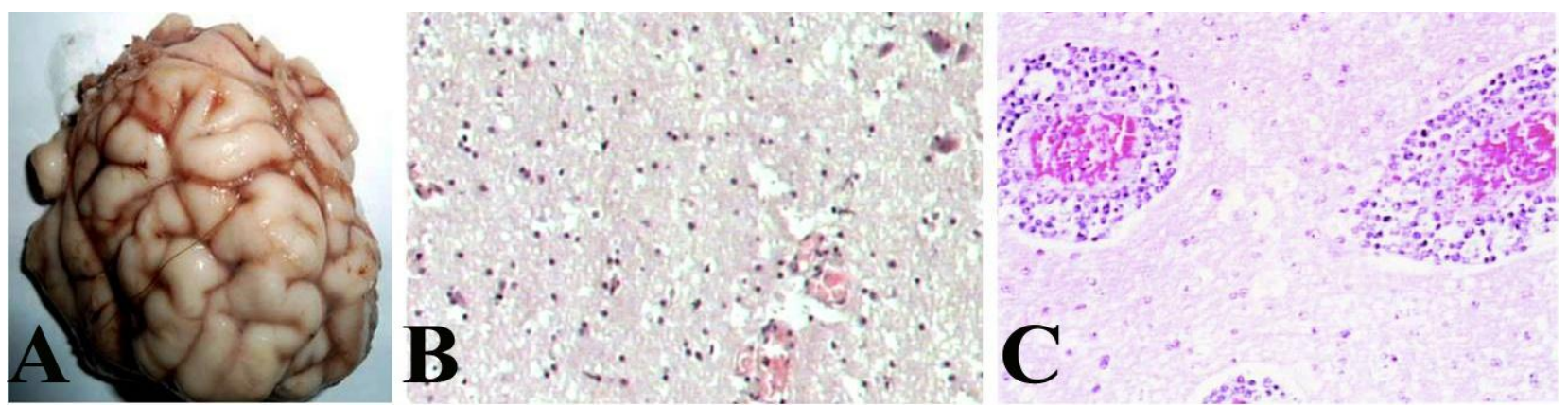

Fig. (4): Camel calf brain showing edema and congestion of the meninges (picture-A) Edema and necrobiotic changes of neuroglia cells with congested blood vessels (slide-B).H\&E.X100. Perivascular cuffing with mononuclear cells infiltration and gliosis in the cerebrum. (slide-C)H\&E.X 400

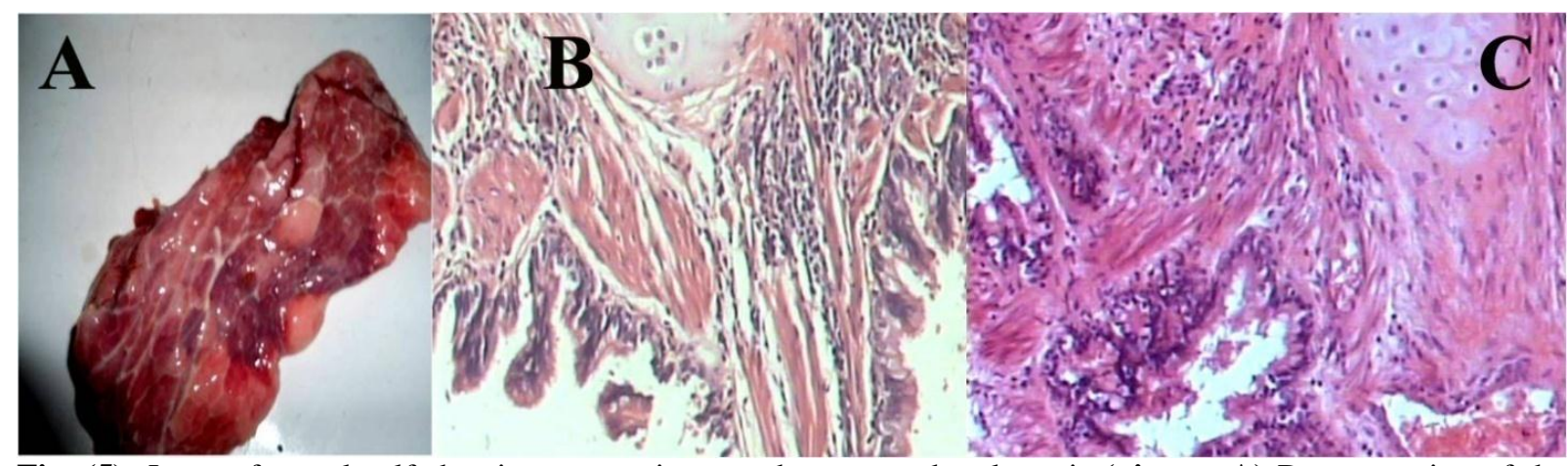

Fig. (5): Lung of camel calf showing congestion, emphysema and atelectasis (picture-A) Desquamation of the lining epithelium of the bronchi with focal accumulation of the inflammatory cells and increased the interalveolar septa (slide-B). Desquamation of cellular exudates admixed with exfoliated necrotic epithelial cells in the bronchial lumina with fibroblastic proliferation (H\&E, X100) (slide-C).

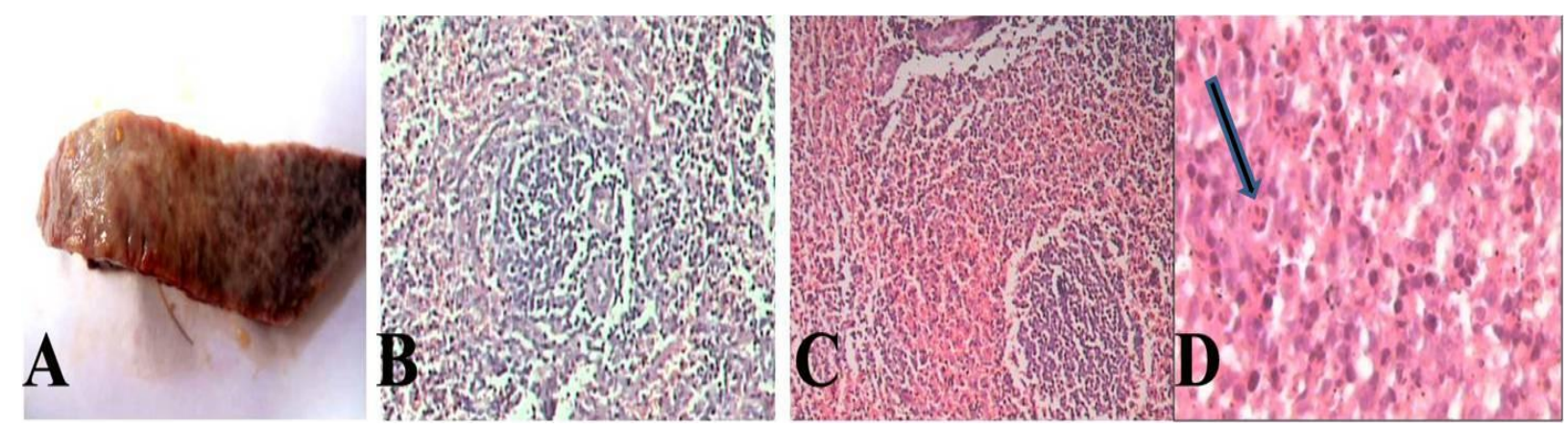

Fig. (6): Spleen of camel calf showing morbid edematous and congested organ (picture-A) Hyperplasia of splenic follicle (slide-B) H\&E.X100. Interstitial edema (slide-C) H\&E.X100. With focal suppuration (live \&dead neutrophiles) black arrow (slide-D) H\&EX400.
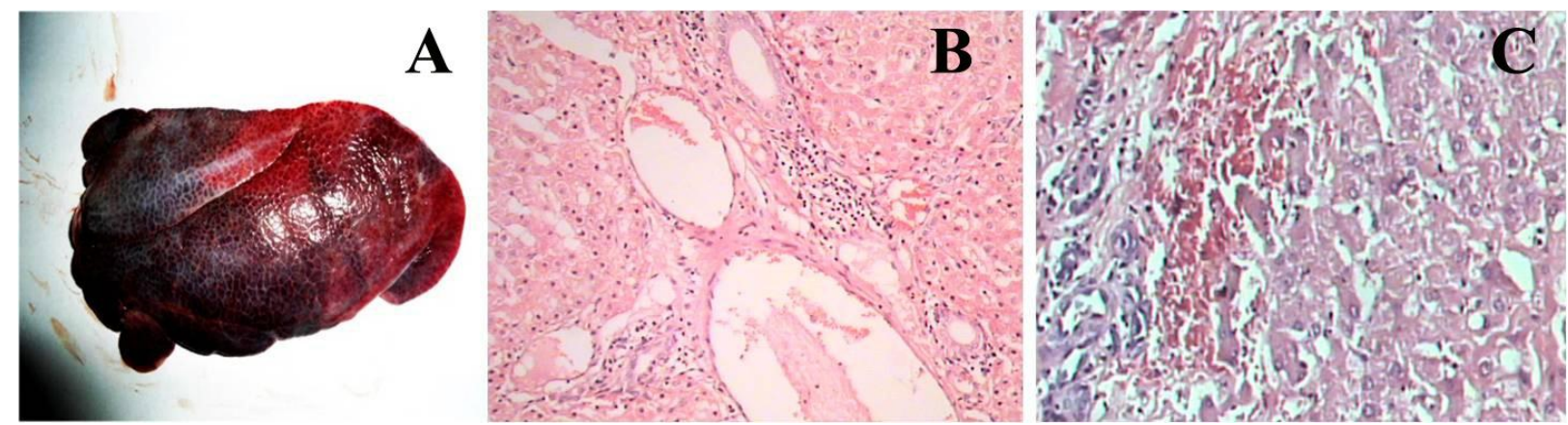

Fig. (7): Liver of camel calf showing hyperemic and edematous organ (picture-A) Edema with vacular degeneration of hepatocytes and inflammatory cells aggregation in the portal area (slide -B). Degenerated \&necrosed hepatocytes with focal heamorrhges and congestion of blood vessels (slide- C). H\&E.X100. 


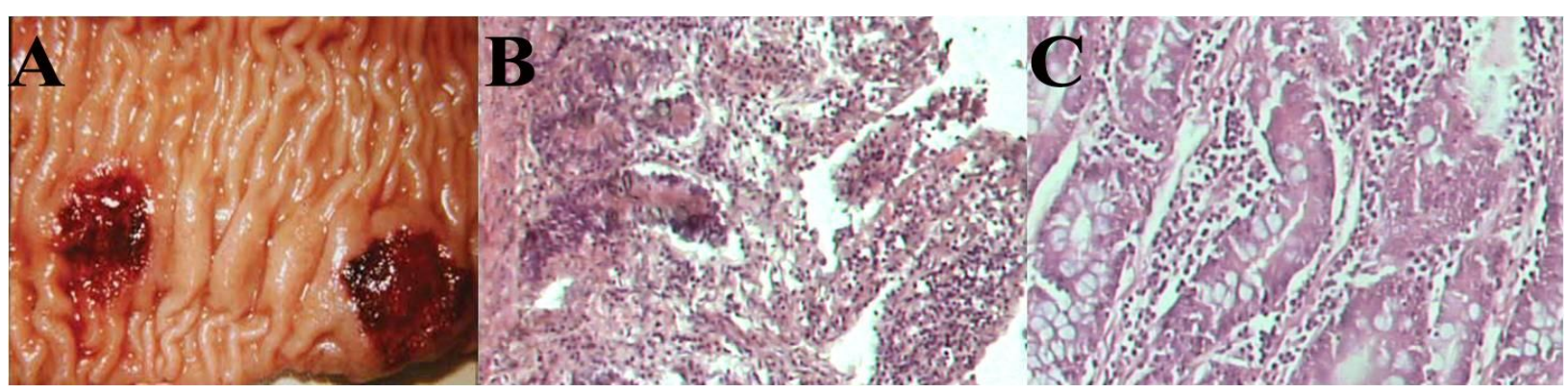

Fig. (8): Small intestine (ileum) of camel calf showing edema, congestion with ulcers on the peyer's patches (picture-A). Degeneration of the intestinal villi with desquamation of its lining epithelium and diffuse inflammatory cells infiltration mainly lymphocytes and neutrophiles (slide-B). Degeneration of the intestinal glands and necrosis of others. Edema and inflammatory cells aggregation in the lamina propria (slide -C). H\&E.X100.
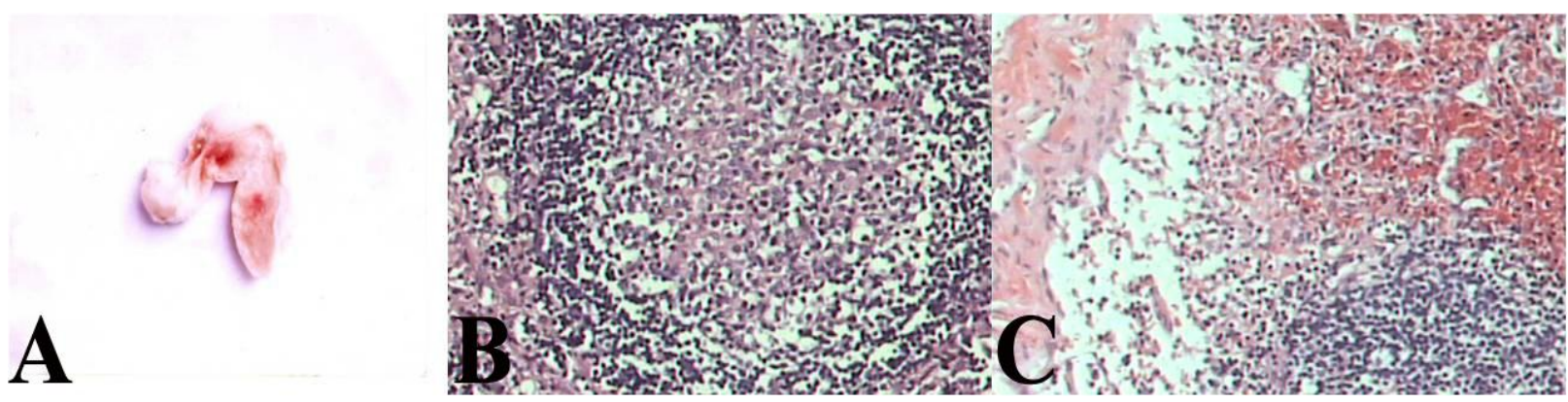

Fig. (9): The mesenteric lymph node of camel calf showing congested and heamorrhgic (picture-A). Follicular hyperplasia with dense infiltration of inflammatory cells mainly lymphocytes and plasma cells (slide-B). Edema with subcapsular heamorrhges (slide-C). H\&E.X100.

\section{DISCUSSION}

Bovine herpes (BHV-1) and bovine viral diarrhoea (BVD) are two of the most important viruses of cattle and other ruminants causing significant diseases (Deregt 1998).

Present observation of the clinical signs of fever, anorexia, listlessness and diarrhoea agree with Baker (1995). Also the respiratory signs as dyspnoea, hyperaemia of the nasal mucosa, and serous discharge from eyes and nose, agree with Jerzy et al. (2005).

Conventional methods for virus isolation are used, with the addition of a final immune-labelling step (fluorescence or enzymatic) to detect growth of non cytopathogenic virus. Thus tube cultures should include flying cover-slips, while plate cultures can be fixed and labelled directly in the plate. (OIE 2008).

The indirect peroxidase staining technique is a practical test for detecting BVDV in infected herds (Meyling 1984) and has been used previously to diagnose BVDV infection (Haines et al., 1992) and IBR (Wyler 1990). Moreover, advantage to immunoperoxidase monolayer plate assay produces intense red brown precipitate which is detected by the naked eye or by light microscopy, without the need of special microscope.

In current work BVDV was detected with similar percentages using IF and IMP techniques similarly, Meyling (1983) notes that the sensitivity of both tests (FA-IMP) are equivalent when it come to diagnosing BVDV.

Although, many authors reported the presence of antibodies of BVDV and BHV-1 alone or in combination in the blood serum of non vaccinated camels with no evidence of gross symptoms or lesions (Alfaleq et al., 2007; Intisar et al., 2009; Raoofi et al., 2010) there were no antibodies detected in the current study, this may be due to the need of larger scale population.

Identification of some pathogens often requires the use of techniques such as assays on tissue culture, oligonucleotide probes, which are time consuming and not economic to be part of the diagnostic laboratory routine (Tramuta et al., 2011). 
The present work highlighted the ability of RT- PCR assay in detection of BVD viral RNA in different types of samples (nasal and fecal swabs, tissue and serum samples) Many authors reported that RT-PCR technique has been used to detect BVDV in various samples such as foetal fluids, tissues, serum, semen, cell cultures and whole blood (Letellier et al., 1999; Lindberg et al., 2002; Stokstad et al., 2003). Also PCR has been developed for detection of BHV-1 in a wide variety of clinical samples such as naturally and artificially infected semen (Deka et al., 2005; Grom et al., 2006), blood (Fuchs et al., 1999), nasal swabs and vaginal swabs (Saha et al., 2010) and faecal swabs (Mahmoud and Ahmed, 2009). In all these studies PCR was found to be accurate, sensitive and fast method for detection of BHV-1.

The ability to perform many PCR assays within a short time frame to detect multiple pathogens can generate valuable information in differential diagnosis. Additional cost benefit on farm will result from more rapid diagnosis and the ability to target treatment (Kurćubić et al., 2013).

Multiplex PCR is used for simultaneous amplification of two or more DNA fragments in the same reaction (Henegariu et al., 1997). As compared to single template PCR, multiplex PCR can reduce the total number of tubes, the cost for the reagents, and possible contamination.

Each pair of primers used in current study was able to identify a highly conserved fragment in both two viruses considered in this work. For example, the BVDV primer set was able to detect all ruminant pestiviruses to help in broad detection and so that the results from this assay become more sensitive and specific. Additionally, when primer pairs were combined in the multiplex assay, no primers interfered with the amplification of the other target.

The multiplex PCR employed in this work assist in simultaneous detection of two important viral pathogen one is RNA virus (BVD) and the other is DNA virus $(\mathrm{BHV}-1)$ therefore it can provide imperative step in rapid reliable diagnosis especially in cases of mixed infection of viral and bacterial pathogen.

The higher percentages of BVDV and BHV-1 detected by PCR in current study may be attributed to the high sensitivity of PCR assay (Vilcek et al., 1994; Grom et al., 2006).

Results of multiplex PCR detected BVDV in serum of one clinically normal camel calf. This may be explained by the information of persistently infected calves may show signs of chronic illnesses; however, they can also appear clinically normal (Grooms et al., 2002) but similar evaluations have not been well described in PI alpacas as most have been diagnosed immediately prior to death due to their normal appearance (Carman et al., 2005; Mattson et al., 2006; Foster et al., 2007 and Byers et al., 2009).

In the present study, the postmortem findings of dead camel calves revealed congestion and hemorrhages of lymph nodes, Similar results were reported by Desouky et al. (2009) Such changes could be due to direct effect of the virus on the blood vessels causing damage of endothelial cells lining. The present work revealed necrobiotic changes of neuroglia cells which showed chromatolysis in addition to gliosis. These results were confirmed by Plant et al. (1983); Loken and Bjerkas, (1991); Hewicker et al. (1995) and Broaddus et al. (2009).

BHV-1, usually damage the respiratory epithelium of the airways and predisposes for entry of pathogenic bacteria. They also inhibit the mucociliary clearance making it possible for invading the bacteria to attach to the pulmonary epithelium (Kumar et al., 2002). The viruses infect the alveolar macrophages and the ciliated epithelium of the lungs thus disrupting its mucociliary transport and also inhibit the phagosomes-lysosome fusion and inhibit the phagocytic ability of macrophages to kill bacteria (Kanel et al., 2005 and Jain et al., 2009). BHV-1 infection alone is not life threatening but it predisposes to secondary bacterial pneumonia that usually ends fatally. The infection can be very severe in young calves and cause a generalized septicemic disease and eventually death (Anon 2006).

Necropsy findings of dead animals revealed inflammation and consolidation of the diaphragmatic and apical lobes in the right and left lungs. There were some adhesions between the lungs and the pleura and cut surface of the lung was frothy, similar findings were recorded by Jain et al. (2009) and Hansan et al. (2009).

Finally vacuolar degeneration, lymphocytic hepatitis, hemorrhagic lymphadenitis and ulcerative enteritis were observed also the lymphoid cells infiltration in several tissues should be taken in consideration. These findings had been determined by Jubb (2007) and Farhang et al. (2013).

\section{CONCLUSION}

The use of multiplex PCR can be rapid cost-effective way for simultaneous detection so that consider a valuable practical diagnostic tool for BVDV and BHV-1 especially in clinical samples. IF and IMP regard as simple confirmative tools for identification of BVDV and BHV-1. BVDV and BHV-1 induced pronounced pathological changes in nervous, respiratory and lymphatic tissues. Lung, brain, 
spleen, intestine, liver and mesenteric $\mathrm{LN}$ are the most susceptible tissues.

\section{ACKNOWLEDGMENTS}

The authors thank prof. Dr/ Saad-M.A.M. Animal Reproduction Research Institute El-Haram, for his collaboration.

\section{REFERENCE}

Abd-Elrahim, I.H.; Abd-Elhakim, U. and Hussein, M. (1999): An epizootic of Rift Valley fever in Egypt in 1997. Rev. Sci. Tech. 18(3): 741-748.

Abd-El Wahab, M.R.; Hussein, H.A. and Shalaby, M.A. (2005): Detection of BVDV Associated with Mortalities in Camels. International journal of virology. Volume: 1, Issue: 1, Pp.: 45-45.

Ahmed, W.M. and Kawther, S.Z. (2008): A Field Contribution on the Relation Between Reproductive Disorders and Bovine Viral Diarrhea Virus Infection in Buffalo-Cows. American-Eurasian J. Agric. \& Environ. Sci., 3 (5): 736-742.

Ackermann, M. and Engels, M. (2006): Pro and contra IBR-eradication. Veterinary Microbiology 113, 293-302.

Al-Afaleq, A.I.; Abu-Elzein, E.M.E.; Hegazy, A.A. and Al-Naeem, A. (2007): Serosurveillance of camels (Camelus dromedarius) to detect antibodies against viral diseases in Saudi Arabia. J Camel Pract Res. 14(2): 91-96.

Amstel, S.V. and Kennedy, M. (2010): Bovine viral diarrhea infections in new world camelids-A review. Small Ruminant Res., 91: 121-126.

Anon, S. (2006): Enozootic pneumonia of calves. The Merck Veterinary Manual. Whitehouse Station, Nature Journal, USA.

Baker, J.C. (1995): The clinical manifestations of bovine viral diarrhea infection. Vet .Clin. North Am. Food Anim. Pract. 11(3): 425-45.

Bancroft, J.D. and Stevens, A. (1990): Theory and Practice of histological Techniques. $3^{\text {rd }}$ edition, New York.

Brock, K.V. (2004): The many faces of bovine viral diarrhoea virus. Vet. Clin. North Am. Food Anim. Pract. Mar; 20(1): 1-3.

Broaddus, C.C.; Lamm, G.; Kapil, S.; Dawson, L. and Holyoak, G.R. (2009): Bovine viral diarrhea virus in goats housed with persistently infected cattle. Vet. Path., 46: 4553.

Byers, S.R.; Kevin, R.S.; Daniel, J.R.; James, F.E.; Daniel, S.B.; Steven, M.P. and George, M.B. (2009): Disseminated bovine viral diarrhea virus in a persistently infected alpaca (Vicugna pacos) cria. J. Vet. Diagn Invest. 2009; 21: 145-148.
Byers, S.R.; James, F.E.; Daniel, S.B.; Amanda, L.G.; Julia, F.R.; Steven, M.P.; Ahmed T.; George, M.B. (2011): The effects of exposure of susceptible alpacas to alpacas persistently infected with bovine viral diarrhea virus. Can Vet. J. 2011; 52: 263-271.

Carman, S.; Carr, N.; DeLay, J.; Baxi, M.; Deregt, D. and Hazlett, M. (2005): Bovine viral diarrhea virus in alpaca: Abortion and persistent infection. J Vet Diagn Invest.; 17: 589-593.

Curtis, R.A.; Van Dreumelt, A.A. and Ditchfield, J. (2001): Infectious bovine Rhinotracheitis clinical, pathological, and virological aspects. Arch. Virol, 146: 633-652.

Deka, D.; Matti Ramneek, N.K. and Oberoi, M.S. (2005): Detection of bovine herpesvirus- 1 infection in breeding bull semen by virus isolation and polymerase chain reaction. Review of Science and Technology Office International des Epizooties, 24, 1085-1094.

Deregt, D. (1998): Infectious bovine rhinotracheitis and bovine viral diarrhoea: repercussions for animal health and international trade. Conf. OIE, 137-146.

Desouky, H.M.; Younis, A.A.; Shalaby, S.A. and Hagazy, A. (2009): Experimental infection with BVD virus in pregnant does with emphasis on pathgological and hormonal changes. European J. Biological Sci., 1: 47-53.

Dragoş, A.; Adriana, A. and Gheorghe, S. (2010): Detection of Bovine Herpesvirus Type 1 by PCR Assay. Bulletin UASVM, Veterinary Medicine 67(2) pp. 23-27.

El-Sabbagh, M.M.; El-Sawalhy, A.A.; Samira, S. Taha and Ghaly, H.M. (2000): "Epidemiological studies on infectious bovine rhinotracheitis, bovine viral diarrhea, parainfluenza-3 and bovine adenovirus type 3 in calves of some governorate in Egypt. Minufiya Vet. J. 1 (1): 373-387.

Farhang, S.; Aida, V.; Javad, J. and Mehdi, A.H. (2013): Detection of infectious bovine rhinotracheitis in natural cases of bovine abortion by PCR and histopathology assays. American J. of Clinical and Experimental Medicine. 1(2): 35-39.

Foster, A.P.; Houlihan, M.G.; Holmes, J.P.; Watt, E.J.; Higgins, R.J.; Errington, J.; Ibata, G. and Wakeley, P.R. (2007): Bovine viral diarrhoea virus infection of alpacas (Vicugna pacos)in the UK. Vet Rec.; 161: 94-99.

Fuchs, M.; Hubert, P.; Detterer, J. and Rziha, H.J. (1999): Detection of bovine herpesvirus type 1 in blood from naturally infected cattle by using a sensitive PCR that discriminates between wild-type virus and virus lacking glycoprotein E. Journal of Clinical Microbiology, 37, 2498-2507. 
Grom, J.; Hostnik, P.; Toplak, I. and BarlicMaganja, D. (2006): Molecular detection of BHV-1 in artificially inoculated semen and in the semen of a latently infected bull treated with dexamethasone. Veterinary Journal, 171, 539-544.

Grooms, D.L.; Baker, J.C. and Ames, T.R. (2002): Diseases caused by bovine viral diarrhea virus. In: Smith BP, editor. Large Animal Internal Medicine. St. Louis, Missouri: Mosby; pp. 707-714.

Haines, D.M.; Clark, E.G. and Dubovi, E.J. (1992): Monoclonal antibody-based immunohistochemical detection of bovine viral diarrhea virus in formalin-fixed, paraffinembedded tissues. Vet. Pathol., 29 (1), 27-32

Hansan, I.; Servet, S.; Simten, Y. and Aynur, S. (2009): Viral and bacterial pathogen isolated and identified from pneumonic calves in Region of Diyarbakir and its treatment with Tulathromycin. Journal of Animal and Veterinary Advances, 8, 1545-1550.

Henegariu, O.; Heerema, N.A.; Dlouhy, S.R.; Vance, G.H. and Vogt, P.H. (1997): "Multiplex PCR: critical parameters and step-by-step protocol." Biotechniques 23(3): 504-11.

Hewicker-Trautwein, M.; Liess, B. and Trautwein, G. (1995): Brain lesions in calves following transplacental infection with bovine virus diarrhoea virus J. Vet.Med. B., 42: 65-77.

Intisar, K.S.; Ali, Y.H.; Khalafalla, A.I.; Mahasin, E.A. and Amin, A.S. (2009): Natural exposure of Dromedary camels in Sudan to infectious bovine rhinotracheitis virus (bovine herpes virus-1). Acta Trop. 111(3): 243-426.

Jain, L.; Kanani, A.N.; Puroh, J.H.; Vinay, K. and Jain, V.K. (2009): Detection of bovine herpes virus 1 (BHV-1) infection in semen of Indian breeding bulls by polymerase chain reaction and its characterization by DNA sequencing. Buffalo Bulletin, 28, 76-84.

Jerzy, R.; Magdalena, L. and Mirosław, P.P. (2005): Detection of bovine herpesvirus 1 from an outbreak of infectious bovine rhinotracheitis. Bull Vet. Inst. Pulawy 49, 267-271.

John, D.N. (2014): Bovine viral diarrhea virus and camelids: adaptation of a viral pathogen to a new host species. National Animal Disease Center, USDA, ARS. Ames, IA $50010 \mathrm{Ph}$ : 515-337-7730; FAX: 515-337-7428.

$J u b b$, K.P. (2007): Pathology of domestic animals, fifth edition. Vol. 1, pp: 429-430.

Kanel, G.; Korula, J. and Jain, V.K. (2005): Atlas of Liver Pathology, 2nd Edition. Elsevier Saunders Publishing, pp36.

Kapil, S.; Yeary, T. and Evermann, J.F. (2009): Viral Diseases of New World Camelids. Vet. Clin. 274 North Am. Food Anim. Pract., 2: 323337.
Kumar, V.L.; Cartan, R.S. and Robbins, S.L. (2002): Robins Basic Pathology,7th Edition. Saunders Inc., Tokyo, pp 483.

Kurćubić1, V.; Đoković1, R.; Vidanović, D.; Šekler, M.; Matović, K.; Ilić, Z. and Stojković, J. (2013): Bovine respiratory disease complex (BRDC): viral and bacterial pathogens in Serbia. Biotechnology in Animal Husbandry 29 (1), p 37-43.

Letellier, C.; Kerkhofs, P.; Wellemans, G. and Vanopdenbosch, E. (1999): Detection and genotyping of bovine diarrhea virus by reverse transcription-polymerase chain amplification of the 5' untranslated region. Veterinary Microbiology 64, 155-67.

Lindberg, A.; Niskanen, R.; Gustafsson, H.; Bengtsson, B.; Baule, C.; Belák, S. and Alenius, S. (2002): Prenatal diagnosis of persistent bovine viral diarrhoea virus (BVDV) infection by detection of viral RNA in fetal fluids. Veterinary Journal 164, 151-155.

Loken, T. and Bjerkas, I. (1991): Experimental pestivirus infections in pregnant goats. J. Comp. Path., 105: 123-140.

Mahmoud, M.A. and Ahmed, S.A. (2009): Prevalence of bovine herpesvirus-1 in sheep and goats in Egypt. Global Veterinaria, 3, 472-479.

Mattson, D.E.; Baker, R.J.; Catania, J.E.; Imbur, S.R.; Wellejus, K.M. and Bell, R.B. (2006): Persistent infection with bovine viral diarrhea virus in an alpaca. J. Am. Vet. Med. Assoc.; 228: 1762-1765.

Moennig, V.; Houe, H.; Lindberg, A. (2005): BVD control in Europe: current status and perspectives. Anim. Health. Res. Rev. Jun; 6(1): 63-74.

Mohamed, K.E.; Ahmad, Mohammad, A.; Ahmed, M.A. and Effat, L.E. (2013): Investigation of the immune status of camels (camelus dromedarius) against some viral diseases. Alexandria Journal of Veterinary Sciences. 39: 12-17.

Meyer, G.; Lemaire, M.; Ros, C.; Belak, K.; Gabriel, A.; Cassart, A.; Oignoul, F.S.; Belak, S. and Thiry, E. (2001): Comparative pathogenesis of acute and latent infections of calves with bovine herpesvirus types 1 and 5 Arch Virol (2001) 146: 633-652.

Meyling, A. (1983): An immunoperoxidase (PO) technique for detection of BVD virus in serum of Clinically and subclinically infected cattle. Proc. 3rd International Symposium World Ass. Vet. Diagnost Lab., Ames, Iowa, 179-184.

Meyling, A. (1984): Detection of BVD virus in viremic cattle by an indirect immunoperoxidase technique. In Recent advances in virus diagnosis. Martinus Nijhoff, The Hague, 37-46. 
Oguzhan, A.; Sibel, Y. and Mehmet, K. (2014): Detection of respiratory viral antigens in cattle lung tissues by direct ELISA. Animal and Veterinary Sciences, 2(5): 146-149.

OIE, (2008): Bovine viral diarrhea. Chapter 2. 4. 8 pp. 698-711.

OIE, (2010): Infectious bovine rhinotracheitis/ infectious pustular vulvovaginitis Chapter 2.4.13. pp.1-17.

Plant, J.W.; Acland, H.M.; Gard, G.P. and Walker, K.H. (1983): Clinical variations of border disease in sheep according to the source of the inoculum. Vet. Record,16: 58-60.

Raoofi, A.; Hemmatzadeh, F. and Ghanaei, A.M. (2010): Serological survey of antibodies against BVD virus in camels (Camelus dromedarius) in Iran. Trop Anim Health Prod. 42(3): 411-4.

Saha, T.; Guha, C.; Chakraborty, D.; Pa, B.; Biswas, U.; Chaterjee, A.; Koenig, P. and Beer, M. (2010): Isolation and characterization of BoHV-1 from cattle in West Bengal, India. Iranian Journal of Veterinary Science Technology, 2, 1-8.

Saliki, J.T.; Fulton, R.W.; Hull, S.R. and Dubovi, E.J. (1997): Microtiter virus isolation and enzyme immunoassays for detection of bovine viral diarrhea virus in cattle serum. Journal of Clinical Microbiol., 35: 803-807.

Sambrook, J.E.; Fritsch, E.F. and Maniates, T. (1989): Molecular coloning laboratory manual. 2nd edition.

Stokstad, M.; Niskanen, R.; Lindberg, A.; Thorén, P.; Belák, S.; Alenius, S. and Løken, T. (2003): Experimental infection of cows with bovine viral diarrhoea virus in early pregnancy findings in serum and foetal fluids. Journal of Veterinary Medicine Series B 50, 424-429.

Tariq, H.T. (2007): Pathogens Affecting the Reproductive System of Camels in the United Arab Emirates. PHD Faculty of Veterinary Medicine and Animal Science Swedish University of Agricultural Sciences (SLU) P.O. Box 7036, SE- 75007 Uppsala, Sweden.

Tramuta, C.; Daniela, L.; Simona, Z.; Mariella, G.; Alessandro, D.; Ezio F.; Patrizia, N. and Sergio, R. (2011): Development of a set of multiplex standard polymerase chain reaction assays for the identification of infectious agents from aborted bovine clinical samples. Journal of Veterinary Diagnostic Investigation 23(4) 657-664.

Vilcek, S.; Nettleton, P.F.; Herring, J.A. and Herring, A.J. (1994): Rapid detection of bovine herpesvirus 1 (BHV 1) using the polymerase chain reaction. Veterinary Microbiology 42, 53-64.

Wentz, P.A.; Belknap, E.B.; Brock, K.V.; Collins, J.K. and Pugh, D.G. (2003): Evaluation of bovine viral diarrhea virus in New World Camelids. J. Am. Vet. Med. Assoc. 223 (2), 223-228.

Wernery, U. and Kaaden, O.R. (1995): Infectious disease of camelids. Blackwell Wissenshalts Verlag, Berlin.

Wyler, $\quad R$. (1990): $\quad$ Infectious bovine rhinotracheitis/vulvovaginitis (BHV-1). In Herpesviridae of cattle, horse and pigs (G. Whittmann, ed.). Kluwer Academic Publishers, Boston, Massachusetts, 1-72.

\section{الإستكثاف الجينى والتغيرات الباثولوجية للإصابة بفيروسى الإسهال البقرى الفيروسى وفيروس الهربس البقرى في عجول الجمال}

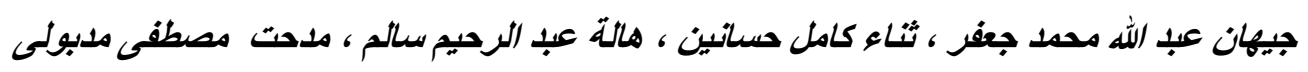

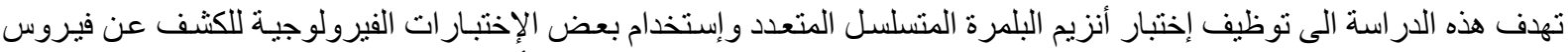

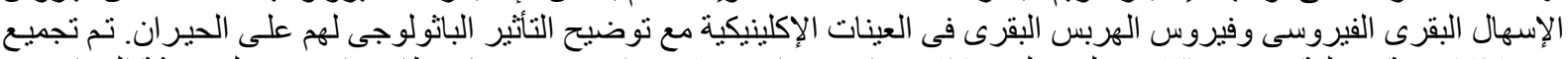

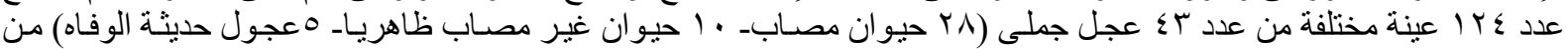

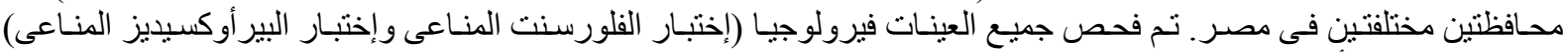

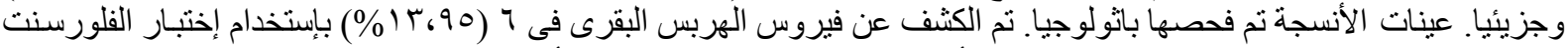

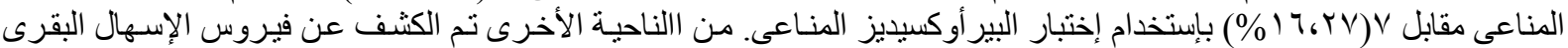

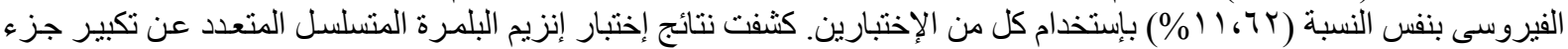

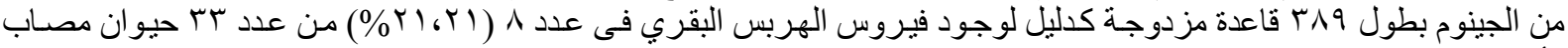

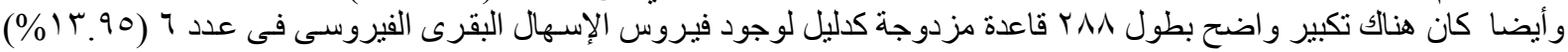

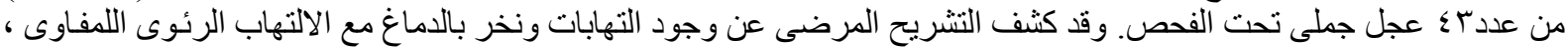

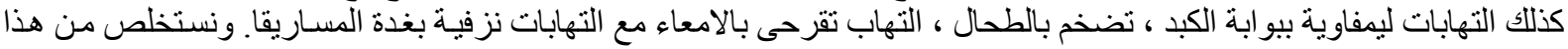

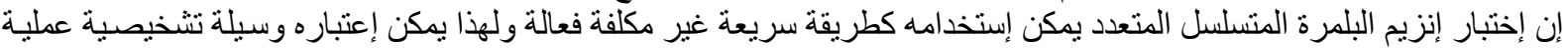

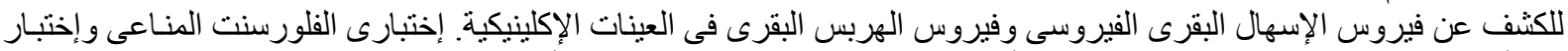

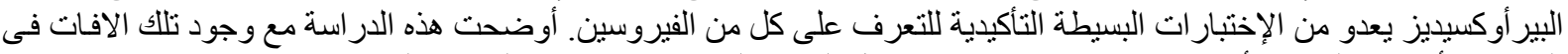

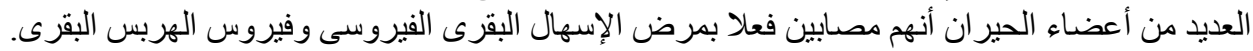

